\title{
Possible Impacts of the Expected Shift from Cow-Calf to Cow-Yearling Enterprises
}

\author{
SULIMAN H. ABDALLA AND JOHN P. WORKMAN
}

\begin{abstract}
Retention of weaner calves to be marketed as yearlings directly from range has been recently suggested as a possible means for the cow-calf operator to cope with the depressed calf market. Although it has been widely recognized that such an adjustment would decrease cow herd carrying capacity and reduce total beef production from range states, these impacts have not been quantified. The purpose of our study was to trace the impacts of shifting from the typical cow-calf operation to a cow-yearling enterprise, using two representative sizes of Utah cattle ranches as examples. Results are reported in terms of reduction in brood cow herd required to accommodate a larger yearling herd, projected impacts on total beef production in Utah, the 11 western states, and the nation, and possible effects on national consumer beef prices.
\end{abstract}

Since the end of World War II, the U.S. beef industry has become increasingiy dependent upon feed grains, primarily due to low grain prices relative to cattle prices. Recently the price picture has changed greatly, with increased world demand for grain forcing feed grain prices up relative to cattle prices, a trend which is expected to continue (Skold 1974). This increased concentrate-forage price ratio will likely make range forage even more important in the beef production process (Acord 1975; Workman 1975). Additional impetus for forage to play a larger role in beef production comes from recent changes in

Authors are graduate research assistant, and associate professor of range economics, Department of Range Science. Utah State University.

This report is published with the approval of the Director, Utah Agricultural Experiment Stution, as Journal Paper No. 2321.

Manuscript received January 17, 1978.
USDA beef grading standards. New USDA grading criteria will allow animals to reach marketable grades with somewhat less finish and at lighter weights. "Inverted" cattle prices of recent years have also provided incentive for increased forage use and less grain feeding. During the past 2 years, heavy feeder cattle have often sold for higher prices per cwt than have weaner calves, a complete reversal of what has come to be considered as the "normal" cattle price situation.

Retention of weaner calves for later sale as yearlings has been widely recommencied as a possible adjustment for the cow-calf operator in order to cope with recently depressed and often “inverted" cattle markets (Brownson et al. 1975; Eisgruber and Nelson 1975). While there has been general agreement that shifts from cow-calf to cow-yearling operations will bring breeding herd reductions of from 17 to $33 \%$ to accommodate larger yearling herds (Kearl 1969; Gee and Skold 1970; Gee and Pursley 1972; Brownson et al. 1975; Eisgruber and Nelson 1975), there have been no attempts to quantify the impacts of the expected shift on total beef production or on beef price.

The purpose of this study was to determine the decrease in breeding herd carrying capacity required to shift from a cowcalf to a cow-yearling operation, the resulting decrease in total beef production in Utah and the 11 western states and the projected impact on U.S. consumer beef prices.

\section{Methods}

Ten alternatives to the traditional cow-calf operation were studied to 
determine the possible impacts of shifting to cow-yearling operations. Forage balance and stock count charts were developed for two representative Utah ranch sizes ( 150 and 300 breeding cows) based on data from Roberts and Gee (1963) and using the methods of Workman and MacPherson (1973). Forage requirements were forced to equal forage availability for all 11 management options. This forced equality formed the basis of breeding herd reductions made necessary by the shift from cow-calf operations to one of the ten cow-yearling options.

Both representative ranch sizes retained $17 \%$ of the heifer calves for cow herd placement. Calf crop percentage, based on number of calves weaned divided by number of cows and heifers at least 2 years of age in the preceding January inventory, was $81 \%$ for the 150 -cow ranch and $82 \%$ for the 300 -cow ranch. A cow/bull ratio of $20 / 1$ prevailed with the bulk of the calves born in April. Cattle spent most of the period November through April on Bureau of Land Management range. Part of the herd was also fed hay, grain, and protein supplement from December 1 through March 1. Private foothill range was grazed May 1 through June 15 and a large part of the cow herd grazed U.S. Forest Service range between mid-June and October 1, returning to grazing crop aftermath until the calves were weaned on November 1.

Livestock management options studied are shown in Figure 1 and include the following:

1. Traditional cow-calf operation with calves weaned and sold November 1 .

2. Cow-short yearling operation with $50 \%$ of weaner calves retained on range, hay, and protein supplement and sold April 1.

3. Cow-short yearling operation with $100 \%$ of weaner calves retained as above and sold on April 1.

4. Cow-short yearling operation with all home-grown weaner calves retained, along with $25 \%$ additional weaner calves purchased November 1, wintered as above, and sold April 1.

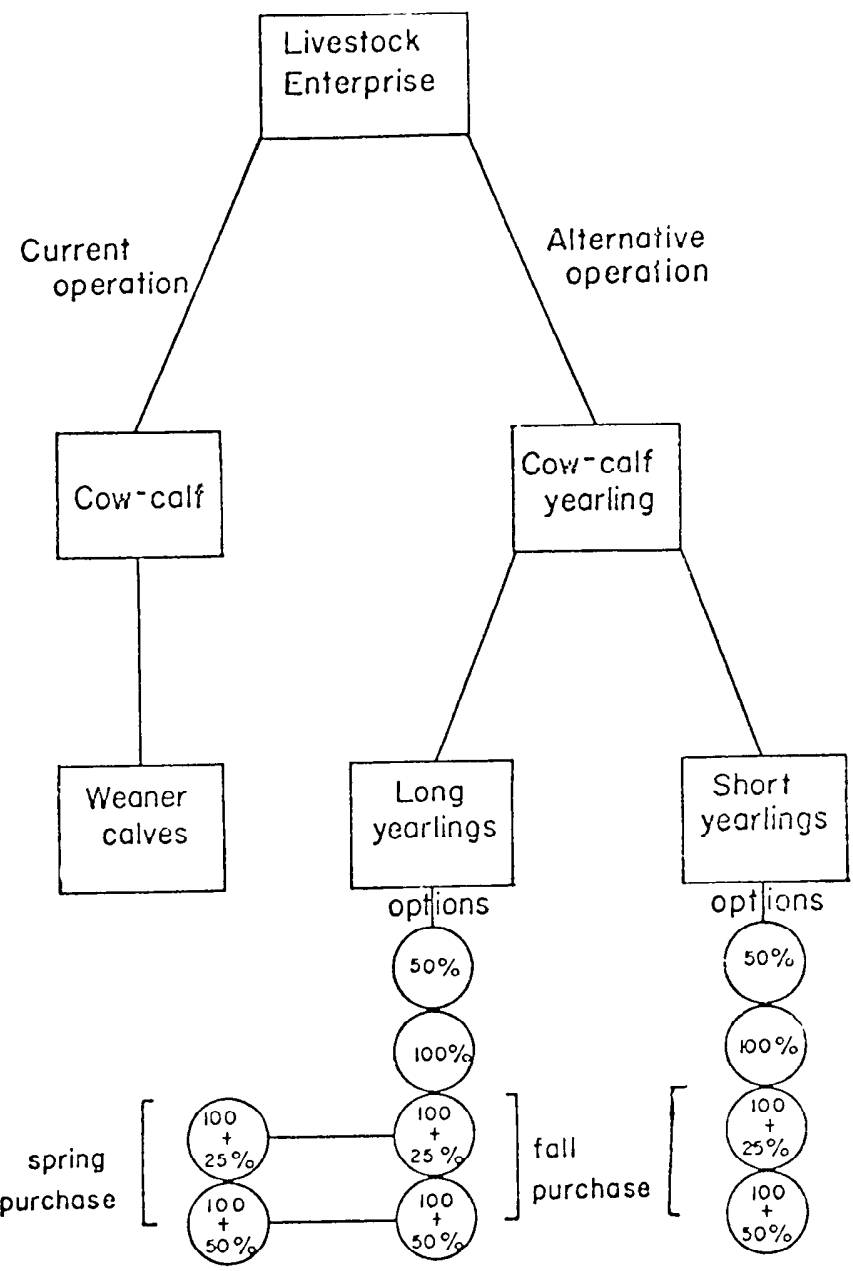

Fig. 1. Projected livestock management options.
5. Cow-short yearling operation with all home-grown weaner calves retained, along with $50 \%$ additional weaner calves purchased November 1, wintered as above, and sold April 1.

6. Cow-yearling operation with $50 \%$ of weaner calves retained, wintered as above, summered on range, and sold October 1 . 7. Cow-yearling operation with $100 \%$ of weaner calves retained, wintered, and summered as above, and sold October 1 .

8. Cow-yearling operation with all home-grown weaner calves retained, along with $25 \%$ additional weaner calves purchased November 1 , wintered and summered as above, and sold October 1. 9. Cow-yearling operation with all home-grown weaner calves retained, along with $50 \%$ additional weaner calves purchased November 1, wintered and summered as above, and sold October 1 . 10. Cow-yearling operation with all home grown weaner calves retained, wintered and summered as above, along with $25 \%$ additional yearlings purchased April 1, and sold October 1 .

11. Cow yearling operation with all home grown weaner calves retained, wintered, and summered as above, along with $50 \%$ additional yearlings purchased April 1 and sold October 1 .

Animal unit equivalents for cattle of various sizes were calculated using

$$
A U=\frac{W^{. \overline{5}}}{1000^{\cdot 7 \overline{5}}}
$$

where $W$ is the average weight (lb) of the animal class in question (Kearl 1970). Breeding herd numbers, along with the associated complement of bulls and replacement heifers, were adjusted to monthly range forage constraints except for the winter season during which purchased hay was allowed to off-set any deficit. Brood cow carrying capacity by month was calculated for each management option and the number of brood cows which could be carried during the most limiting period (usually April or May) was taken as the maximum yearlong breeding herd carrying capacity for each option. The required reduction in brood cows to accommodate retained yearlings was then calculated along with the resulting reduction in number of calves produced.

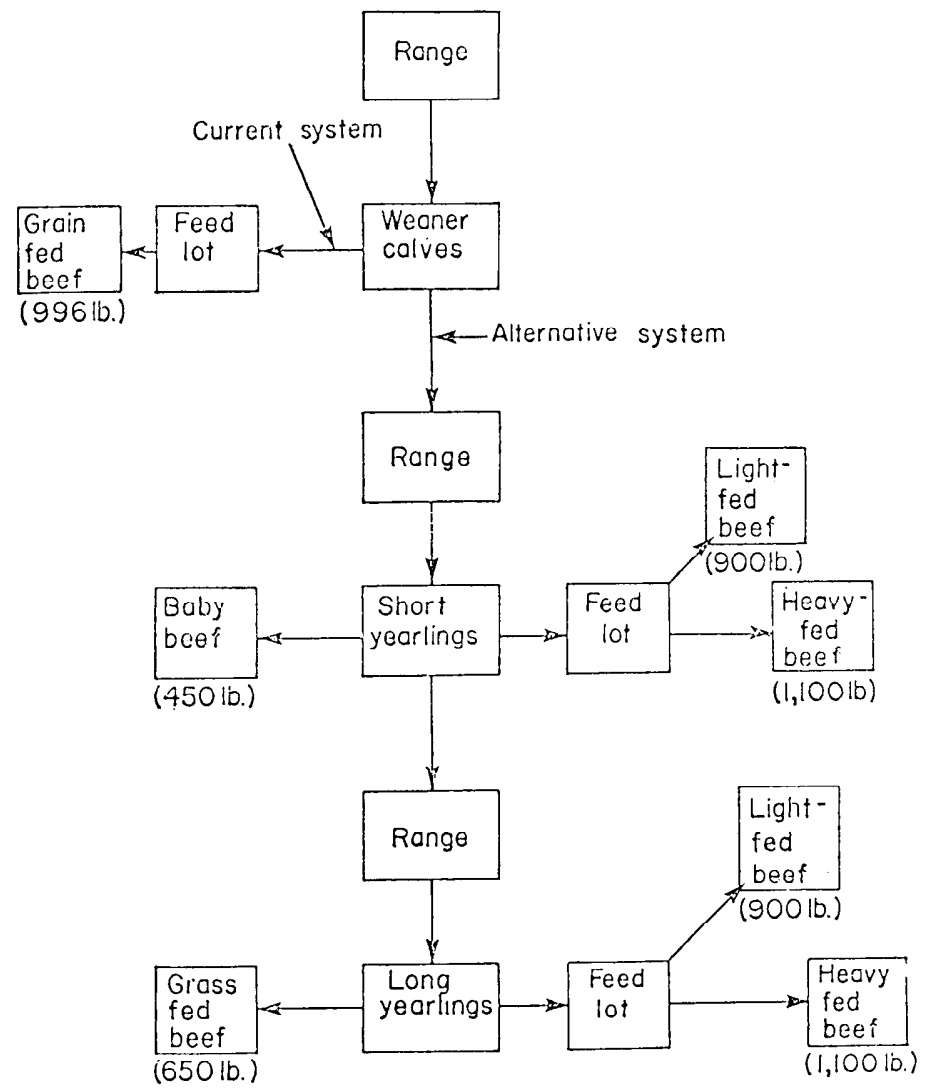


Determination of the reduction in becf production due to shifts from cow-calf to cow-yearling operations was based on 1975 beef production data (Statistical Reporting Service 1975). Four possible beef feeding and marketing strategies were superimposed over the 11 management alternatıves to determine a variety of possible impacts on beef production. The four strategies shown in Figure 2, included sale of (a) baby-beef, (b) grass-fed beef. (c) light-fed beef, and (d) heavy-fed beef. Baby-beef are defined for purposes of this study as short-yearling calves marketed at an average weight of $450 \mathrm{lb}$ after feeding primarily on mother's milk and range forage. Grass-fed beef are long-yearling calves which have fed on range or pasture and have received a limited grain ration just prior to being marketed at an average weight of $650 \mathrm{lb}$. Light-fed beef are cattle which remain on range or pasture until they are short- or long-yearlings and then finished on grain to an average weight of $900 \mathrm{lb}$. Heavy-fed cattle are cattle grazed on range and pasture to short- or long-yearlings and then finished on grain to an average weight of $1,100 \mathrm{lb}$.

Changes in beef production due to the shift from cow-calf to cow-yearling operations were based on adoption of each option by $50 \%$ of all Utah or 11 Western states ranchers. Beef production figures for 1975 (Statistical Reporting Service 1975) formed the basis of both number and weights of animals marketed under the existing management and marketing system (cow-calf operation with calves ultimately marketed from the feedlot at an average weight of $966 \mathrm{lb}$ ).

Impacts on beef prices due to each of the possible changes in beef production were determined using the concept of elasticity of demand. An elasticity of demand coefficient of -.67 (Workman et al. 1972) was used to calculate the percentage increase in beef prices which would result from the adoption of various cow-yearling options.

\section{Results and Discussion}

\section{Required Breeding Herd Reduction}

Year-long brood-cow carrying capacities and the required cow herd reductions to accommodate each management option are shown in Table 1 . As expected, the extent of required cow herd reduction depended on the number of calves retained or purchased. Even niore important than calf numbers, however, was the time of year during which weaners or yearlings were retained on the ranch. Weaner calves kept only until April 1 did not cut into breeding herd carrying capacity. Calves retained or purchased after April 1, though, caused significant reductions in cow herd size. This was due to the "bottleneck" range forage period of April and May. During these 2 months, range forage is just beginning growth and production levels are low. However, the small amount of forage produced is very lush and causes cattle to turn away irom hay as an effective supplement and may also lead to poisonous plant ingestion if cattle are left out on the range. If cattle are penned to enable hay to be fed effectively and to avoid poisonous plant problems, the attendant wet and muddy conditions may lead to cattle health problems, including calf scours.

Thus, the longer calves are retained, the larger the required decrease in broodi-cows. Since retention of long-yearlings involved keeping calves during the spring ' bottleneck,' longyearling operations brought cow herd reductions of from 8 to $31 \%$, while short-yearling options left the cow herd unchanged.

Table 1. Brood cow carrying capacity under 11 different management options.*

\begin{tabular}{|c|c|c|c|c|c|c|}
\hline \multirow[b]{2}{*}{ No. } & \multirow[b]{2}{*}{ Option } & \multicolumn{2}{|c|}{$\begin{array}{c}\text { Brood cow } \\
\text { carrying capacity } \\
\end{array}$} & \multicolumn{3}{|c|}{$\begin{array}{l}\text { Decrease in brood cow } \\
\text { carrying capacity }\end{array}$} \\
\hline & & $\begin{array}{l}150-\text { cow } \\
\text { ranch } \\
\text { (head) }\end{array}$ & $\begin{array}{l}\text { 300-cow } \\
\text { ranch } \\
\text { (head) }\end{array}$ & $\begin{array}{l}150-\text { cow } \\
\text { ranch } \\
(\%)\end{array}$ & $\begin{array}{l}300-\text { cow } \\
\text { ranch } \\
(\%)\end{array}$ & $\begin{array}{l}\text { Combined } \\
\text { Average } \\
(\%)\end{array}$ \\
\hline 0 & Basic cow-calf operation & 150 & 300 & 0 & 0 & 0 \\
\hline I & $\begin{array}{l}50 \% \text { of the calves retained and sold as short- } \\
\text { yearlings }\end{array}$ & 150 & 300 & 0 & 0 & 0 \\
\hline II & $\begin{array}{l}100 \% \text { of the calves retained and sold as short- } \\
\text { yearlings }\end{array}$ & 150 & 300 & 0 & 0 & 0 \\
\hline III & $\begin{array}{l}100 \% \text { of the calves retained with } 25 \% \text { additional } \\
\text { calves purchased and sold as short-yearlings }\end{array}$ & 150 & 300 & 0 & 0 & 0 \\
\hline IV & $\begin{array}{l}100 \% \text { of the calves retained with } 50 \% \text { additional } \\
\text { calves purchased and sold as short-yearlings }\end{array}$ & 150 & 300 & 0 & 0 & 0 \\
\hline V & $\begin{array}{l}50 \% \text { of the calves retained and sold as long- } \\
\text { yearlings }\end{array}$ & 136 & 280 & 9.3 & 6.7 & 8.0 \\
\hline VI & $\begin{array}{l}100 \% \text { of the calves retained and sold as long- } \\
\text { yearlings }\end{array}$ & 117 & 240 & 22.0 & 20.0 & 21.0 \\
\hline VII & $\begin{array}{l}100 \% \text { of the calves retained with } 25 \% \text { additional } \\
\text { calves purchased (Nov. 1) and sold as long- } \\
\text { yearlings }\end{array}$ & 109 & 225 & 27.3 & 25.0 & 26.2 \\
\hline VIII & $\begin{array}{l}100 \% \text { of the calves retained with } 50 \% \text { additional } \\
\text { calves purchased (Nov. 1) and sold as long- } \\
\text { yearlings }\end{array}$ & 103 & 211 & 31.3 & 29.7 & 30.5 \\
\hline IX & $\begin{array}{l}100 \% \text { of the calves retained with } 25 \% \text { additional } \\
\text { calves purchased (Apr. 1) and sold as long- } \\
\text { yearlings }\end{array}$ & 109 & 225 & 27.3 & 25.0 & 26.2 \\
\hline$X$ & $\begin{array}{l}100 \% \text { of the calves retained with } 50 \% \text { additional } \\
\text { calves purchased (Apr. 1) and sold as long- } \\
\text { yearlings }\end{array}$ & 103 & 211 & 31.3 & 29.7 & 30.5 \\
\hline
\end{tabular}


Table 2. Changes in beef production in Utah, the Western region, and the United States*, based on $50 \%$ adoption level for the different management and marketing options.

\begin{tabular}{|c|c|c|c|c|c|c|c|c|c|c|c|c|c|}
\hline \multirow[b]{3}{*}{ No. } & \multirow[b]{3}{*}{ Management option } & \multicolumn{12}{|c|}{$\%$ change in beef tonnage by the adoption of marketing option } \\
\hline & & \multicolumn{3}{|c|}{ Baby-beef } & \multicolumn{3}{|c|}{ Grass-fed beef } & \multicolumn{3}{|c|}{ Light-fed beef } & \multicolumn{3}{|c|}{ Heavy-fed beef } \\
\hline & & State & Region & Nation & State & Region & Nation & State & Region & Nation & State & Region & Nation \\
\hline 0. & Basic option (cow-calf) & 0 & & & & & & & & & & & \\
\hline \multicolumn{14}{|c|}{ Options Selling Short-Yearlings } \\
\hline I. & $50 \%$ of the calves retained & -6.2 & -4.0 & -1.8 & - & - & - & 4.2 & 3.4 & -.4 & 9.0 & 6.8 & 0.4 \\
\hline II. & $100 \%$ of the calves retained & -12.4 & -8.0 & -3.8 & - & - & - & 8.4 & 7.0 & -.6 & 17.8 & 13.6 & 0.8 \\
\hline III. & $\begin{array}{l}100 \% \text { of the calves retained with } 25 \% \\
\text { additional purchased calves }\end{array}$ & -15.6 & -10.2 & -.46 & - & - & - & 10.6 & 8.6 & -.8 & 22.2 & 17.0 & 0.8 \\
\hline IV. & $\begin{array}{l}100 \% \text { of the calves retained with } 50 \% \\
\text { additional purchased calves }\end{array}$ & -18.8 & -12.2 & -5.6 & & & & 12.8 & 10.4 & -1.0 & 26.8 & 20.4 & 1.0 \\
\hline \multicolumn{14}{|c|}{ Options Selling Long-Yearlings } \\
\hline V. & $50 \%$ of the calves retained & - & - & - & -4.7 & -2.4 & -1.6 & 1.2 & 1.4 & -.8 & 5.2 & 4.4 & -0.2 \\
\hline VI. & $100 \%$ of the calves retained & - & - & - & -9.6 & -6.0 & -3.2 & -0.4 & 0.6 & -2.0 & 7.0 & 6.0 & -0.8 \\
\hline VII. & $\begin{array}{l}100 \% \text { of the calves retained with } 25 \% \\
\text { additional calves purchased November } 1\end{array}$ & - & - & - & -11.8 & -7.4 & -4.0 & -1.0 & 0.4 & -2.4 & 7.6 & 6.6 & -1.2 \\
\hline VIII. & $\begin{array}{l}100 \% \text { of the calves retained with } 50 \% \\
\text { additional calves purchased November } 1\end{array}$ & - & - & - & -13.6 & -8.6 & -4.6 & -1.4 & 0.2 & -2.8 & 8.4 & 7.2 & -1.4 \\
\hline IX. & $\begin{array}{l}100 \% \text { of the calves retained with } 25 \% \\
\text { additional calves purchased April } 1\end{array}$ & - & - & - & -11.8 & -7.4 & -4.0 & -1.0 & 0.4 & -2.4 & 7.6 & 6.6 & -1.2 \\
\hline X. & $\begin{array}{l}100 \% \text { of the calves retained with } 50 \% \\
\text { additional calves purchased April } 1\end{array}$ & - & - & - & -13.6 & -8.6 & -4.6 & -1.4 & 0.2 & -2.8 & 8.4 & 7.2 & -1.4 \\
\hline
\end{tabular}

"Changes in beef production in the nation were based on the adoption of the different management and marketing options by the Western region producers.

\section{Changes in Utah Beef Production}

Beef production in Utah for 1975 was 267.7 million lb. The combined average weight for cattle and calves marketed was $718 \mathrm{lb}$ per head. Calculated changes in beef production in Utah depended on number and weight of animals marketed (Table 2). Since the adoption of short-yearling management options did not decrease the number of animals marketed, marketing weight of animals determined the amount of beef produced. Longyearling options resulted in a considerable decrease in number of animals marketed, and hence the amount of beef produced was a combined effect of both number and weight of animals marketed.

Total Utah beef production decreased by marketing babybeef $(6.2$ to $18.8 \%)$, grass-fed beef ( 4.2 to $13.6 \%)$, and light-fed long-yearlings $(0.4$ to $1.4 \%)$. The decrease in beef production due to marketing baby-beef resulted from a reduction of market weights from the current average of $718 \mathrm{lb} / \mathrm{head}$ to a projected weight of $450 \mathrm{lb}$. The reduction from marketing grass-fed beef was due to both the weight decrease (from $718 \mathrm{lb}$ to $650 \mathrm{lb}$ ) and the 2.8 to $14.8 \%$ reduction in number of animals marketed. For the light-fed long yearling option, the increase in market weight (from $718 \mathrm{lb}$ to $900 \mathrm{lb}$ ) was offset by a dccrease in number of animals marketed resulting in a decline in total beef production of 0.4 to $1.4 \%$.

Short-yearling options marketing light-fed animals at $900 \mathrm{lb}$ produced a considerable beef production increase $(4.2$ to $12.8 \%$ ). This increase was greater than that resulting from marketing heavy-fed long-yearlings $(5.2$ to $8.4 \%)$ and about half the increase due to marketing heavy-fed short-yearlings ( 9 to $26.8 \%$ ).

\section{Changes in Western Region Beef Production}

In 1975 , the 11 western state region contributed about $21 \%$ ( 8.3 billion $\mathrm{lb}$ ) to national beef production (Statistical Reporting
Service 1975). The weighted average market weight for cattle and calves in the region was $692 \mathrm{lb}$ per head.

As in Utah, baby-beef and grass-fed beef options brought a decline in regionai beef production, while grain-finished options resulted in regional becf production increases (Table 2). Both positive and negative changes were slightly smaller than the corresponding changes in Utah due to differences in average marketing weights and the contribution of locally produced calves to total area beef production in the two areas. Both current average marketing weight per head $(718 \mathrm{lb})$ and the contribution of local calves were higher in Utah than in the region.

\section{Changes in National Beef Production}

Unlike the effects in Utah and the region, adoption of the projected management and marketing options by $50 \%$ of all Western region producers brought decreases in national beef production under all projected options with the exception of the short-yearling option marketing heavy-fed beef (Table 2). The decline in national beef production was due to the high current national average market weight of beef cattle $(996 \mathrm{lb} / \mathrm{head})$ as compared to the projected market weights of all options except heavy-fed beef $(1,100 \mathrm{lb} /$ head). Even when the projected market weight was greater than the national average, as in the case of heavy-fed long-yearlings, the beef increase due to market weight was off-set by the reduction in number of animals marketed due to retention of long-yearlings.

Marketing of baby-beef or grass-fed beef in the region resulted in about equal decreases in national beef production ( 1.8 to $5.6 \%$ and 1.6 to $4.6 \%$, respectively). Due to the reduction in number of animals marketed, long-yearling options showed greater decreases in beef production than did the short-yearling options. 
Comparisons of Beef Production Effects in the State, Region, and the Nation

As shown in Table 2, direction of change in beef production due to the various projected management options was similar in Utah and the Western region although they differed in amount of change. In both geographic areas, marketing of baby-beef and grass-fed beef caused a significant decrease in beef production; and the higher the retention of weaner calves and yearlings and the lower the marketing weights, the greater the decrease. Both light-and heavy-fed short-yearling options caused a greater beef production increase in both Utah and the region than did longyearling options.

Beef production changes at the national level were not proportional to changes in Utah and the region. The Western region contributed only $21 \%$ of total national beef production (Statistical Reporting Service 1975) but the impacts of projected regional management options on national beef production were about twice a large as would be expected. For example, marketing baby-beef caused beef production to decrease by 4 to $12.2 \%$ in the region and by 1.8 to $5.6 \%$ in the nation. Based on the regional contribution of $21 \%$, the regional decrease of 4 to $12.2 \%$ would be expected to cause a national beef decrease of from 0.8 to $2.4 \%$, or about one half the actual decrease. This

Table 3. Changes in beef market price based on $50 \%$ adoption level for the different management and marketing options.

\begin{tabular}{|c|c|c|c|c|c|}
\hline \multirow[b]{2}{*}{ No. } & \multirow[b]{2}{*}{ Management option } & \multicolumn{4}{|c|}{$\%$ Change in beef market price } \\
\hline & & Baby-becf & $\begin{array}{c}\text { Grass-fed } \\
\text { beef }\end{array}$ & $\begin{array}{l}\text { Light-fed } \\
\text { beef }\end{array}$ & $\begin{array}{c}\text { Heavy-fed } \\
\text { beef }\end{array}$ \\
\hline 0 . & Basic option (cow-calf) & 0.0 & 0.0 & 0.0 & 0.0 \\
\hline
\end{tabular}

Options Selling Short-Yearlings

I. $50 \%$ of the calves retained

2.6

0.6

$-0.6$

II. 100\% of the calves retained

$1.2-1.2$

III. $100 \%$ of the calves retained with $25 \%$ additional purchased calves

6.8

IV . $100 \%$ of the calves re-

tained with $50 \%$ additional purchased calves

8.4

$1.4-1.4$

Options Selling Long-Yearlings

V. $50 \%$ of the calves retained

VI. $100 \%$ of the calves retained

VII. $100 \%$ of the calves retained with $25 \%$ additional calves purchased November 1

VIII. $100 \%$ of the calves retained with $50 \%$ additional calves purchased November 1

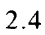

3.6

1.8

6.8

4.2

2.0

IX. $100 \%$ of the calves retained with $25 \%$ additional calves purchased April 1

X. $100 \%$ of the calves retained with $50 \%$ additional calves purchased April 1 disproportionality casts doubt on the accuracy of the $21 \%$ beef production contributed by the Western region. The disparity may be due to the fact that a considerable portion of the calves raised in the Western region are finished in states outside the region. The additional beef produced by finishing these feeder calves is reflected in the average weight of beef cattle marketed nationally but not in the average weight of animals marketed in the Western region. Thus, the reductions in national production give a better indication of actual beef contribution by the region. The true contribution includes (1) the direct contribution, measured in terms of total beef produced in the region, and (2) the indirect contribution of supplying feeder calves to states outside the region.

The only option resulting in a national beef increase was the marketing of heavy-fed short-yearlings. Again, the increase in national beef production $(.4$ to $1 \%$ ) was not proportional to the regional increase (o.8 to $20.4 \%$ ). The small national increase, resulting from a much larger regional increase, was due to the production shift into the Western region from other regions. Thus, additional production from finishing beef cattle which previously took place outside the region is now done inside the region. Although it would boost regional beef production in the region, such a shift would obviously have little effect on national beef supply.

\section{Beef Prices}

Changes in consumer beef prices are shown in Table 3. As expected, price changes followed the trends in national beef supply. The projected regional marketing options resulted in an increase in national beef prices except for the heavy-fed shortyearling option, which gave an estimated price decrease of from 0.6 to $1.4 \%$. The highest price increases resulted from marketing baby-beef ( 2.6 to $8.4 \%$ ) and grass-fed beef ( 2.4 to $6.8 \%$ ).

\section{Summary and Conclusions}

Retention of weaned calves to be marketed as yearlings directly from the range has recently been suggested as a possible means for the cow-calf operator to cope with the depressed calf

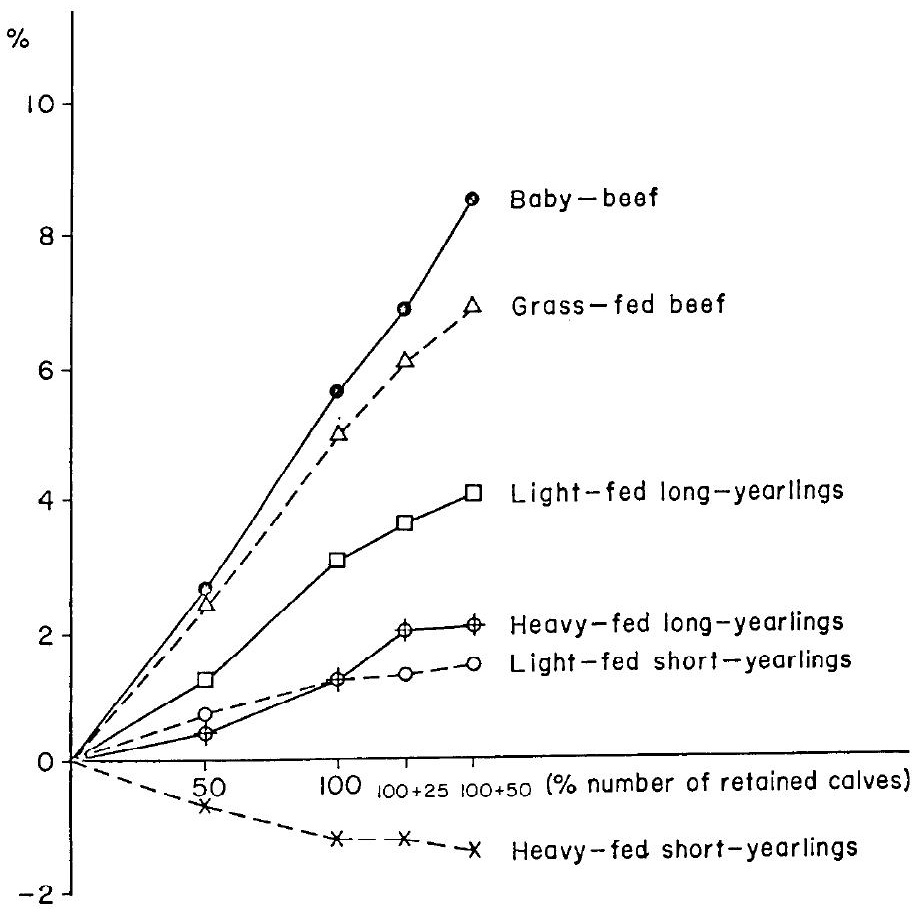

Fig. 3. Estimated changes in consumer beef prices. 
market. This study showed that the longer calves were retained, the larger the required decrease in brood cows. Retention of long-yearlings brought reductions of from 8 to $31 \%$, while short-yearling options left the cow herd unchanged.

Changes in beef production depended on number and weight of animals marketed. Non-grain finished marketing options caused a significant decrease in beef production in Utah, the Western region, and the nation. This decrease was due mainly to lower marketing weights. In grain-finished options, the number of animals marketed was the primary factor determining the amount and direction of beef production changes. Since shortyearling options left the number of animals marketed unchanged, both light and heavy grain-finishing of short yearlings brought considerable beef increases at the state and regional levels. Long-yearling options, however, greatly reduced the number of animals marketed and even heavy grain-finishing produced less beef than light grain-finishing of short-yearlings.

Since the Western region supplies feeder calves to states outside the region, a decrease in regional production would reduce national beef supply more than would be suggested by regional beef contribution statistics. On the other hand, light or heavy grain-finishing, which would boost regional beef production, would have little effect on national beef supply. Grain finishing options in the Western region actually represent only a shift in tinished beef production to the Western region from surrounding states.

In terms of total national beef supply, the current cattlc production system is clearly superior to all others studied except for marketing heavy-fed short-yearlings. With the high grain prices and depressed feeder calf market of recent years, it may be difficult to maintain the existing system. Heavy grain feeding of short-yearlings would require almost as much grain as current production methods. On the other hand, marketing yearlings as baby-beef or grass-fed beef would result in a substantial decrease in beef production and corresponding increases in beef prices. As long as feed grains are available, it is unlikely that either of these options will be adopted by ranchers and feeders.
The best options for producers and feeders will continue to depend on cconomic feasibility. Marketing light-fed shortyearlings and heavy-fed long-yearlings would reduce grain dependence and nearly maintain current national beef production levels. These two options will likely be adopted if feed grain prices remain high relative to beef prices. Even if these options are adopted in the Western region, a moderate increase in consumer beef prices seems unavoidable.

\section{Literature Cited}

Acord, C.R. 1975. Forage-fattened cattle-a new look at an old practice. Utah Sci. 36:19-20.

Brownson, R., R.J. McConnen, and M.S. Stauber. 1975. Cow-calf versus cow-yearling beef systems: a break even analysis. Staff paper. Montana State Univ., Bozeman. 40 p.

Eisgruber, L., and G. Nelson. 1975. The cowman's management options for 1975 and beyond. Preprint Report. Oregon State Univ., Extension Serv. Corvallis. 22 p.

Gee, K.C., and J.K. Purseley. 1972. The economics of retained ownership of calves on eastern Colorado cattle ranches. Colorado Agr. Exp. Sta. Bull. 5515

Gee, K.C., and M.D. Skold. 1970. Optimum enterprise combinations and resources use on mountain cattle ranches in Colorado. Colorado Agr. Exp. Sta. Bull. 5465.

Kearl, W.G. 1969. Comparative livestock systems for Wyoming northern plains cattle ranching. Wyoming Agr. Exp. Sta. Bull. 504.

Kearl, W.C. 1970. Comparison of net energy and animal unit month standards in planning livestock teed and forage requirements. Wyoming Agr. Exp. Sta. Res. J. 35. June, 1970.

Roberts, K.N., and K.C. Gee. 1963. Cattle ranches using public ranges yearlong-income adjustments for grazing fee and permit changes. Agr. Exp. Sta. Bull. 440, Utah State Univ.

Skold, M.D. 1974. Forage requirements to meet future mead production demands. Livestock and Meat situation. LMS-197. July 1974. p. 29-32.

U.S.D.A. Statistical Reporting Service. 1975. Livestock and meat statistics. Suppl. Statistical Bull. 522, 1975. p. 28, 29, 65, 105 and 107.

Workman, J.P. 1975. Speculation on future beef production on rangeland. Rangeman's J. 2:113-114.

Workman, J.P., and D. MacPherson. 1973. Calculating yearlong carrying capacity - an algebraic approach. J. Range Manage. 26:274-277.

Workman, J.P., S.L. King, and J.F. Hooper. 1972. Price elasticity of demand for beef and range improvement decisions. J. Range Manage. $25: 338-341$

\title{
Denver, Colorado • August 14-18, 1978
}

\author{
edited by Donald N. Hyder
}

A truly international group of authors discusses rangelands of the world-their plants, soils, management, ecosystem, animals, inventory, economics, and the societies that live on them. The book includes author and general indices, original illustrations by Harold $\mathrm{F}$. Heady, and minutes of the business meetings of the historic congress. Hard-bound, 742 pages $81 / 2 \times 11$ inches: $\$ 60.00$ postpaid. (For airmail include an additional $\$ 20.00$ U.S.)

Society for Range Management

2760 West Fifth Avenue

Denver, Colorado 80204

USA 